\title{
The Effect of GDP, Inflation, Exchange Rate, Interest Rate on Stock Price Index In Early Warning System: An Empirical Study In ASEAN-5 Countries
}

\author{
Embun Prowantaa \\ Faculty of Economics and Business, \\ Perbanas Institute, Indonesia \\ Faculty of Economics and Business, \\ University of Brawijaya Malang, Indonesia \\ Moeljadib \\ Faculty of Economics and Business, \\ University of Brawijaya Malang, Indonesia

\section{Sumiati} \\ Faculty of Economics and Business, \\ University of Brawijaya Malang, Indonesia

\section{Kusuma Ratnawati} \\ Faculty of Economics and Business, \\ University of Brawijaya Malang, Indonesia
}

\begin{abstract}
The objective of the study is to develop an early warning system (EWS) using macroeconomic (gross domestic product, inflation, exchange rate and interest rate) on stock price index in five ASEAN countries (Indonesia, Malaysia, Singapore, Philippines, and Thailand). We used panel data regression and multiple discriminant analyst (MDA) methods to build an early warning system for ASEAN-5 countries. Early warning system of each ASEAN-5 is a model to simulate changes in macroeconomic variables will affect the sensitivity and behavior of ASEAN countries both as a whole and each country against the stock price index. We find that ASEAN 5 countries are sensitive when macroeconomic variables increase and decreasi simultaneously. An autoregressive integrated moving-average (ARIMA) method is used robustness test to early warning system to predict stock price index ASEAN-5 countries. The result of prediction using ARIMA method shows that stock price index Indonesia, Philippines and Thailand are bullish. On the other hand, stock price index Malaysia and Singapore are bearish.
\end{abstract}

Keywords: Macroeconomic; Early Warning System; Stock Price Index; Bullish; Bearish.

\section{INTRODUCTION}

In the last two decades there have been two major financial crises, namely the Asia financial crisis of 1997 and the global financial crisis of 2008. The main cause of the economic crisis in 1997 was the local currency depreciated greatly against the USD. Another cause was the lack of transparency in ASEAN countries in managing state finances and the banking industry did not implementing risk management properly, so that the banking sector in conducting its business was less prudent. The economic crisis of 2008 was mainly triggered by financial engineering innovations such as subprime mortgage and speculation in the property industry and inaccurate credit ratings by rating agencies in the United States. The result of financial engineering was the collapse of international financial institutions in the United States such as 
Lehman Brothers and Goldman Sachs. Some ASEAN countries such as Malaysia, Singapore and Thailand are also experiencing the impact of the economic crisis with a large financial deficit and negatif economic growt. The economic crisis has a significant effect on the drastic decline of the stock price index.

Capital markets play an important role in the economic and political development of a country. Drastic decline in the stock price index in a short and sustainable, it will trigger a financial crisis and push into an economic recession. Most of the major capital markets in the world are strongly influenced by the global financial crisis [9].

The economic crisis of 1997 and 2008 spread the economy of other countries so that in a relatively short time it had become a global crisis because of the contagious effect in the midst of the global financial system and the rapid dissemination of information. Each country needs to mitigate risks by creating an early warning system (EWS) to anticipate the occurrence of an economic crisis.

This research was conducted to develop an early warning system in five ASEAN countries by using the stock price index as the dependent variable. The research previously conducted by [10] used the Financial Stress Index (FSI), while the research conducted by [17] used the market instability index as the dependent variable for the early warning system model. This research is an innovation from previous research on early warning systems.

\section{LITERATURE REVIEW}

The economic crisis has always been linked to unfavorable macroeconomic conditions, where high economic growth is not supported with strong economic fundamentals that the resulting in bubble economy. Macroeconomic variables have a significant influence on the stock price index according research [1], so that macroeconomic variables can be used in building an early warning system against potential economic crisis.

Research conducted by [13] used macroeconomic variables on the stock price index to find that the exchange rate has negative significant effect and inflation rate has positive significant in Sri Lankan Stock Market. Inflation and interest rate have a negative significant effect on stock price index. Moreover, exchange rate and GDP have a positive and significant affect on stock price index five ASEAN Countries [13]. [2] found that GDP and exchange rate have a positive significant effect and CPI has a negative significant effect on the stock price index in Thailand. However, the value of exports, money supply (M2), foreign direct investment, and oil price did not have a significant effect on the stock price index in Thailand.

Macroeconomic variables are considered to be an indicator of the crisis [8]. To anticipate the economic crisis requires an early warning system. Early warning systems need to be developed by using macroeconomic variables as indicators that affect the stock price index, so as to detect the occurrence of regional financial crisis with reference to the economic crisis of 2008. ASEAN countries need an early warning system in detecting the risk of economic crisis, so that it can immediately implement policy measures to prevent the worst possible consequences of the economic crisis.

The multiple discriminant analysis (MDA) method is used in developing early warning system for each of the five ASEAN-5 countries which is then simulated to know the sensitivity and behavior of each ASEAN-5 countries if a change of macroeconomic variables to the stock price index. Using the multiple discriminant analysis (MDA) model is easier, simpler and able to answer research objectives compared to other models. 
According to [15] the results of discriminant analysis can be used as a basis for constructing simulations. [7], [11] examined the sensitivity of stock prices to the announcement of macroeconomic conditions and the results showed that monetary policy significantly affected stock prices.

Simulation model used various factors to explain the dynamics of capital market volatility. Research conducted by [12], [6], [4], describe the simulation model by observing capital market volatility during recession or expansion by varying as a change in macroeconomic variables. This proves that the volatility of the capital market has a cyclical pattern that tends to be influenced by economic turmoil.

The ARIMA model comes from a statistical model perspective and is known to be robust and efficient in forecasting financial series especially short-term predictions. [14] doing research the best ARIMA model for predicting market capitalization 21 Infrastructural Sector Companies listed in India. ARIMA investigation is applied for 21 companies secluded the firms into three categories i.e. companies on an upward trend, linear trend and downward trend.

\section{METHODOLOGY}

The objective of the study is to build an early warning system (EWS) using macroeconomic monthly data from 2006 to 2015 as independent variables (gross domestic product, inflation, exchange rate and interest rate) to the dependent variable on stock price index in five ASEAN countries (Indonesia, Malaysia, Singapore, Philippines, and Thailand). Early warning system is to analyze the level of sensitivity and behavior of ASEAN-5 countries as a whole and each country against the stock price index if there is a change of macroeconomic variables.

Population used in this study is the macroeconomic data and stock price index from five ASEAN countries. Samples used in this study using sampling techniques saturated, so all the population is used as a sample in the study.

This type of data from this research is secondary data in the form and type of research is explanatory research. By determining monthly data from 2006 to 2015 for the variables in this study were taken five variables consisted of four independent variables and one dependent variable. The independent variables in this study consisted of gross domestic product (GDP), inflation (INF), exchange rate (EXCH), interest rate (INT). While the dependent variable in this study is the stock price index of the five ASEAN countries (Y) consists of Indonesia, Malaysia, Singapore, the Philippines and Thailand.

\section{Panel Data Regression Method}

To test the data of macroeconomic variables (GDP, inflation, exchange rate, interest rate) of five ASEAN countries which significantly influence the stock price index using panel data regression method as a basis in establishing an early warning system.

Panel data regression method is a general statistical technique used to analyze the relationship between several independent variables to one dependent variable and (Hair et al., 2006). The purpose of using panel data regression method to test the macroeconomic variable (gross domestic product (GDP), inflation, exchange rate, interest rate) as independent variable that significantly influence the stock price index in five ASEAN countries as the dependent variable. The multiple regression equation is as follows:

$$
Y_{i}=\beta_{0}+\beta_{1} X_{1 t}+\beta_{2} X_{2 t}+\beta_{3} X_{3 t}+\beta_{4} X_{4 t}+e_{i}
$$


The data panel model formula using the fixed effect model is as follows:

$$
Y_{i t}=\alpha+\beta X_{1 t}+\gamma_{2} W_{2 t}+\gamma_{3} W_{3 t}+\cdots+\gamma_{N} W_{N T}+\sigma_{2} Z_{i t}+\sigma_{3} Z_{i 3}+\ldots+\sigma_{T} Z_{i T}+\varepsilon_{i t}
$$

\section{Multiple Discriminant Analysis Method}

This study uses multiple discriminant analysis (MDA) with single dichotomous dependent variable using 0 (zero) as bearish and 1 (one) bullish. The multiple discriminant analysis (MDA) method is used to create an early warning system for each ASEAN-5 countries. The purpose of multiple discriminant analysis is to estimate the relationship between single dependent variable nonmetric (categorical) and a set of independent metric variables (Hair et al., 2006). The general form:

$$
\mathrm{Y}_{1}=\mathrm{X}_{1}+\mathrm{X}_{2}+\mathrm{X}_{3}+\ldots .+\mathrm{X}_{\mathrm{n}}
$$

The discriminant function is the selected independent variable for the discriminatory power used in the prediction of group membership. The predicted value of the discriminant function is the discriminant $\mathrm{Z}$ score, which is calculated for each object in the analysis (Hair et al., 2006). The form of linear equation as follows:

$$
Z_{j k}=a+W_{1} X_{1 k}+W_{2} X_{2 k}+\ldots .+W_{n} X_{n k}
$$

Chi-square is used to test the hypothesis by using statistics to examine the differences between the two groups obtained from relations with Wilks' lambda. If there are significant differences between the groups further discriminant analysis can be done, so it is necessary to do hypothesis testing. Ho states that among the samples no group differences were formulated by:

$$
\begin{aligned}
& \mathrm{H}_{0}: \mu_{1}=\mu_{2}=\ldots \ldots=\mu_{\mathrm{k}} \\
& \mathrm{H}_{1}: \mu_{1} \neq \mu_{2} \quad \mathrm{~S}_{\mathrm{i}, \mathrm{j}}=1,2, \ldots, \mathrm{k} \text { (2 different groups). }
\end{aligned}
$$

The discriminant function for the differentiator should use a cut score. A cut score is a criterion against the discriminant score of each object compared to determine which groups should be classified. The calculation of the cut score between the two groups was based on two groups of centroids with the following cutting score formula:

$$
\mathrm{Z}_{\mathrm{CE}}=\underline{\mathrm{Z}_{\mathrm{A}}}+\frac{\underline{\mathrm{Z}}_{\mathrm{B}}}{2}
$$

When the cutter score has been calculated, each observation can be classified by comparing the discriminant score against the cut score (Hair et al., 2006). Classification in group 0 (bearish) if less than discriminant score while in group 1 (bullish) if more than discriminant score.

\section{ARIMA Method}

The autoregressive integrated moving-average (ARIMA) method uses past data and current data to produce accurate short-term predictions. ARIMA method will work well if the time series data used are dependent or related to each other statistically. The ARIMA method developed by Box et al. (1994) refers to the set of procedures for identifying, matching and checking the ARIMA model with time series data. Model selection in Box-Jenkins technique is done by observing the distribution of autocorrelation coefficient and partial autocorrelation coefficient. 
In general, Box-Jenkins model is formulated in notation as follows: ARIMA (p, $d, q$ ) with $p$ denotes the order / degrees Auto-Regressive (AR), d denotes the order / degree of Differencing, q Shows the Moving-Average (MR). ARIMA model with the formula (Box and Reinsel, 1994).

$$
Y_{t}=\phi_{0}+\phi_{1} Y_{t-1}+\phi_{2} Y_{t-2}+\cdots+\phi_{p} Y_{t-p}+\varepsilon_{t}-\omega_{1} \varepsilon_{t-1}-\omega_{2} \varepsilon_{t-2} \cdots-\omega_{q} \varepsilon_{t-q}
$$

The ARIMA model is determined by the number of independent variable periods of both the lag of the dependent variable $\left(\mathrm{Y}_{\mathrm{t}}\right)$ and the residual value of the previous period. As an example

$$
\begin{array}{rr}
Y_{t}=\phi_{0}+\phi_{1} Y_{t-1}-\omega_{1} \varepsilon_{t-1}+\varepsilon_{t} & \text { (model ARIMA }(1,0,1)) \\
Y_{t}=\phi_{0}+\phi_{1} Y_{t-1}+\phi_{2} Y_{t-2}-\omega_{1} \varepsilon_{t-1}+\varepsilon_{t} & \text { (model ARIMA }(2,0,1))
\end{array}
$$

\section{Panel Data Regression}

\section{FINDING AND DISCUSSION}

The result of panel data regression as follows:

Table 1. The result of panel data regression

\begin{tabular}{|c|c|c|c|c|c|}
\hline Variable & Coefficient & Std. Error & t-Statistic & Prob. & Conclusion \\
\hline GDP & 13.27604 & 3.004526 & 4.418679 & 0.0000 & Significant \\
\hline INF & -56.23924 & 6.360746 & -8.841611 & 0.0000 & Significant \\
\hline EXCH & 0.478076 & 0.014427 & 33.13804 & 0.0000 & Significant \\
\hline INT & -161.4381 & 17.55164 & -9.197890 & 0.0000 & Significant \\
\hline C & 2411.956 & 71.72623 & 33.62725 & 0.0000 & \\
\hline
\end{tabular}

The result of data processing using the fixed effect model can be obtained by multiple regression equation as follows:

$\mathrm{INDEX}=2411.956+13.27604 \mathrm{GDP}-56.23924 \mathrm{INF}+0.478076 \mathrm{EXCH}-161.4381 \mathrm{INT}$

\section{Multiple Discriminant Analysis}

Multiple discriminant analysis (MDA) measures the influence of independent variables on dependent variables under various conditions so that the test in this study determined that $Y=$ 0 is the indicator for bearish and $Y=1$ is an indicator for bullish. Both indicators then become an outline of the influence of independent variables on the dependent variable $(\mathrm{Y})$ as a whole. The next step perform test of equality of group means.

Test of equality of group means is a test of significance between groups of each variable. In this test will look at any independent variables, which differ significantly between groups categorized as bullish or bearish. The table describes the test of equality of group mean. 
Table 2. The effect of GDP, inflation, exchange rate, interest rate to stock price index

\begin{tabular}{|c|c|c|c|c|c|c|c|c|c|c|}
\hline \multicolumn{10}{|c|}{ Tests of Equality of Group Means } \\
\hline \multirow{2}{*}{ Variable } & \multicolumn{2}{|c|}{ Indonesia } & \multicolumn{2}{c|}{ Malaysia } & \multicolumn{2}{c|}{ Philippines } & \multicolumn{2}{c|}{ Singapore } & \multicolumn{2}{c|}{ Thailand } \\
\cline { 2 - 12 } & $\begin{array}{c}\text { Wilks' } \\
\text { Lambda }\end{array}$ & Sig. & $\begin{array}{c}\text { Wilks' } \\
\text { Lambda }\end{array}$ & Sig. & $\begin{array}{c}\text { Wilks' } \\
\text { Lambda }\end{array}$ & Sig. & $\begin{array}{c}\text { Wilks' } \\
\text { Lambda }\end{array}$ & Sig. & $\begin{array}{c}\text { Wilks' } \\
\text { Lambda }\end{array}$ & Sig. \\
\hline PDB &, 951 &, $016^{* *}$ &, 994 &, 397 &, 850 &, $000^{* *}$ &, 788 &, $000^{* *}$ & 1.000 &, 869 \\
\hline INF &, 951 &, $015^{* *}$ &, 999 &, 741 &, 647 &, $000^{* *}$ &, 975 &, $085^{*}$ &, 448 &, $000^{* *}$ \\
\hline EXCH &, 381 &, $000^{* *}$ &, 925 &, $002^{* *}$ &, 974 &, $077^{*}$ &, 852 &, $000^{* *}$ &, 951 &, $015^{* *}$ \\
\hline INT &, 811 &, $000^{* *}$ &, 992 &, 326 &, 677 &, $000^{* *}$ &, 769 &, $000^{* *}$ &, 912 &, $001^{* *}$ \\
\hline
\end{tabular}

Note ${ }^{*}$ ) significant at level $10 \%{ }^{* *}$ ) significant at level $5 \% . \mathrm{Y}=0$ (bearish) and $\mathrm{Y}=1$ (bullish)

The discriminant function of sorting which one goes into one group (bullish) and the other group (bearish). Wilk's lambda table there is one test of function (s).

Table 3. Wilks' Lambda Test

\begin{tabular}{|l|c|c|c|c|c|}
\hline \multirow{2}{*}{ Country } & \multicolumn{5}{|c|}{ Wilks' Lambda } \\
\cline { 2 - 7 } & $\begin{array}{c}\text { Test of } \\
\text { Function(s) }\end{array}$ & $\begin{array}{c}\text { Wilks' } \\
\text { Lambda }\end{array}$ & Chi-square & df & Sig. \\
\hline Indonesia & 1 & 0,307 & 136,915 & 4 & 0,000 \\
\hline Malaysia & 1 & 0,907 & 11,349 & 4 & 0,023 \\
\hline Philippines & 1 & 0,298 & 140,556 & 4 & 0,000 \\
\hline Singapore & 1 & 0,446 & 93,689 & 4 & 0,000 \\
\hline Thailand & 1 & 0,357 & 119,549 & 4 & 0,000 \\
\hline
\end{tabular}

A significant number of 0,000 is below 0.05 then there is a significant difference between the mean of the discriminant function, then the data behavior for both categories of groups is different. The calculation result using discriminant analysis yields equation in early warning system (EWS) to build simulation with discriminant equation result as follows:

Table 4. Canonical discriminant function coefficients

\begin{tabular}{|l|c|c|c|c|c|}
\hline Variables & Indonesia & Malaysia & Philippines & Singapore & Thailand \\
\hline GDP & 1,224 &, 192 &, 654 &, 003 &, 002 \\
\hline INF &,- 002 &,- 213 &,- 464 &,- 005 &, 008 \\
\hline EXCH &, 001 & 3,019 &, 713 &,- 073 &,- 001 \\
\hline INT &,- 018 &, 436 &,- 782 &, 076 &, 002 \\
\hline (Constant) & $-16,414$ & $-12,087$ & $-30,247$ & 6,830 &, 727 \\
\hline
\end{tabular}

Discriminant functions as early warning system for each ASEAN country as follows:

$\mathrm{D}_{\mathrm{INA}}=-16,414+1,224 \mathrm{GDP}-0,002 \mathrm{INF}+0,001 \mathrm{EXCH}-0,018 \mathrm{INT}$

$\mathrm{D}_{\mathrm{MLY}}=-12,087+0,192 \mathrm{GDP}-0,213 \mathrm{INF}+3,019 \mathrm{EXCH}+0,436 \mathrm{INT}$

$\mathrm{D}_{\mathrm{PHL}}=-30,247+0,654 \mathrm{GDP}-0,454 \mathrm{INF}+0,713 \mathrm{EXCH}-0,782 \mathrm{INT}$

$\mathrm{D}_{\mathrm{SGP}}=6,830+0,003 \mathrm{GDP}-0,005 \mathrm{INF}-0,073 \mathrm{EXCH}+0,076 \mathrm{INT}$

$\mathrm{D}_{\mathrm{THD}}=0,727+0,002 \mathrm{GDP}+0,008 \mathrm{INF}-0,001 \mathrm{EXCH}+0,002$ INT

\section{Simulation Model}

Based on the results of discriminant equations can be used as a basis for simulation to determine the sensitivity of macroeconomic variables to the stock price index of each of the five ASEAN countries. Determining the cutting score of each equation in each country to classify a data entry in the category $\mathrm{Y}=0$ is the indicator for bearish and $\mathrm{Y}=1$ is an indicator for bullish. Here is the value of cutting score for each country. 
Table 5. Functions at Group Centroids

\begin{tabular}{|c|c|c|c|c|c|}
\hline Group & Indonesia & Malaysia & Philippines & Singapore & Thailand \\
\hline Bullish & 1.417 & 0.307 & 2.038 & 2.102 & 1.013 \\
\hline Bearish & -1.566 & -0.329 & -1.138 & -0.581 & -0.175 \\
\hline Cutting Score & -0.075 & -0.011 & 0.450 & 0.761 & 0.419 \\
\hline
\end{tabular}

If the score is less than cutting score then it goes into category $Y=0$ (bearish) whereas if score value is bigger than cutting score then enter into category $\mathrm{Y}=1$ (bullish).

The simulation is based on discriminant analysis result to see the sensitivity of share price index of each ASEAN country if there is a change of macro economic variable (GDP, inflation, exchange rate, interest rate). The simulation is done by raising and lowering the macroeconomic variable by $5 \%$ with the following equation:

$$
\mathrm{y}^{\prime}=\mathrm{y}+\mathrm{y}^{*} 0,05 \text { and } \mathrm{y}^{\prime}=\mathrm{y}-\mathrm{y} * 0,05
$$

$\mathrm{y}^{\prime}=$ simulation results and $\mathrm{y}=$ macro variables are simulated

Conduct simulations to measure sensitivity to changes in the increase and decrease of $5 \%$ of the macroeconomic variables of ASEAN-5 countries partially or simultaneously. The results table of the measurement of the sensitivity of each of the five ASEAN countries on partial changes in macroeconomic variables or simultaneously with simulations obtained the following results:

Table 5. GDP simulation results up 5\%

\begin{tabular}{|l|r|l|r|l|l|}
\hline Calculation & \multicolumn{1}{c|}{ IND } & \multicolumn{1}{c|}{ MLY } & \multicolumn{1}{l|}{ PLP } & \multicolumn{1}{l|}{ SNG } & \multicolumn{1}{l|}{ THL } \\
\hline Base & $59,17 \%$ & $34,17 \%$ & $44,17 \%$ & $22,50 \%$ & $29,17 \%$ \\
\hline Simulation Result & $62,50 \%$ & $35,00 \%$ & $45,83 \%$ & $22,50 \%$ & $29,17 \%$ \\
\hline Change & $5,63 \%$ & $2,44 \%$ & $3,77 \%$ & $0,00 \%$ & $0,00 \%$ \\
\hline
\end{tabular}

Table 6. GDP simulation results down $5 \%$

\begin{tabular}{|l|c|r|r|r|c|}
\hline Calculation & \multicolumn{1}{|c|}{ IND } & \multicolumn{1}{c|}{ MLY } & \multicolumn{1}{c|}{ PLP } & \multicolumn{1}{c|}{ SNG } & \multicolumn{1}{c|}{ THL } \\
\hline Base & $59,17 \%$ & $34,17 \%$ & $44,17 \%$ & $22,50 \%$ & $29,17 \%$ \\
\hline Simulation Result & $54,17 \%$ & $34,17 \%$ & $41,67 \%$ & $22,50 \%$ & $32,50 \%$ \\
\hline Change & $-8,45 \%$ & $0,00 \%$ & $-5,66 \%$ & $0,00 \%$ & $11,43 \%$ \\
\hline
\end{tabular}

Table 7. Inflation simulation results up 5\%

\begin{tabular}{|l|c|c|c|c|c|}
\hline Calculation & IND & MLY & PLP & SNG & THL \\
\hline Base & $59,17 \%$ & $34,17 \%$ & $44,17 \%$ & $22,50 \%$ & $29,17 \%$ \\
\hline Simulation Result & $59,17 \%$ & $34,17 \%$ & $43,33 \%$ & $21,67 \%$ & $29,17 \%$ \\
\hline Change & $0,00 \%$ & $0,00 \%$ & $-1,89 \%$ & $-3,70 \%$ & $0,00 \%$ \\
\hline
\end{tabular}

Table 8. Inflation simulation results down $5 \%$

\begin{tabular}{|l|r|r|r|r|r|}
\hline Calculation & \multicolumn{1}{|c|}{ IND } & \multicolumn{1}{c|}{ MLY } & \multicolumn{1}{c|}{ PLP } & \multicolumn{1}{c|}{ SNG } & \multicolumn{1}{c|}{ THL } \\
\hline Base & $59,17 \%$ & $34,17 \%$ & $44,17 \%$ & $22,50 \%$ & $29,17 \%$ \\
\hline Simulation Result & $59,17 \%$ & $35,00 \%$ & $44,17 \%$ & $22,50 \%$ & $30,83 \%$ \\
\hline Change & $0,00 \%$ & $2,44 \%$ & $0,00 \%$ & $0,00 \%$ & $5,71 \%$ \\
\hline
\end{tabular}


Table 9. Exchange rate simulation results up 5\%

\begin{tabular}{|l|l|l|l|l|l|}
\hline Calculation & IND & MLY & PLP & SNG & THL \\
\hline Base & $59,17 \%$ & $34,17 \%$ & $44,17 \%$ & $22,50 \%$ & $29,17 \%$ \\
\hline Simulation Result & $63,33 \%$ & $54,17 \%$ & $57,50 \%$ & $18,33 \%$ & $30,83 \%$ \\
\hline Change & $7,04 \%$ & $58,54 \%$ & $30,19 \%$ & $-18,52 \%$ & $5,71 \%$ \\
\hline
\end{tabular}

Table 10. Exchange rate simulation results down $5 \%$

\begin{tabular}{|l|c|c|c|c|c|}
\hline Calculation & IND & MLY & PLP & SNG & THL \\
\hline Base & $59,17 \%$ & $34,17 \%$ & $44,17 \%$ & $22,50 \%$ & $29,17 \%$ \\
\hline Simulation Result & $53,33 \%$ & $28,33 \%$ & $15,00 \%$ & $25,00 \%$ & $26,67 \%$ \\
\hline Change & $-9,86 \%$ & $-17,07 \%$ & $-66,04 \%$ & $11,11 \%$ & $-8,57 \%$ \\
\hline
\end{tabular}

Table 11. Interest rate simulation results up $5 \%$

\begin{tabular}{|l|r|r|r|r|r|}
\hline Calculation & \multicolumn{1}{|c|}{ IND } & \multicolumn{1}{c|}{ MLY } & \multicolumn{1}{c|}{ PLP } & \multicolumn{1}{c|}{ SNG } & \multicolumn{1}{c|}{ THL } \\
\hline Base & $59,17 \%$ & $34,17 \%$ & $44,17 \%$ & $22,50 \%$ & $29,17 \%$ \\
\hline Simulation Result & $59,17 \%$ & $35,83 \%$ & $41,67 \%$ & $23,33 \%$ & $29,17 \%$ \\
\hline Change & $0,00 \%$ & $4,88 \%$ & $-5,66 \%$ & $3,70 \%$ & $0,00 \%$ \\
\hline
\end{tabular}

Table 12. Interest rate simulation results down $5 \%$

\begin{tabular}{|l|r|r|r|r|r|}
\hline Calculation & \multicolumn{1}{|c|}{ IND } & \multicolumn{1}{c|}{ MLY } & \multicolumn{1}{c|}{ PLP } & \multicolumn{1}{c|}{ SNG } & \multicolumn{1}{c|}{ THL } \\
\hline Base & $59,17 \%$ & $34,17 \%$ & $44,17 \%$ & $22,50 \%$ & $29,17 \%$ \\
\hline Simulation Result & $59,17 \%$ & $34,17 \%$ & $45,00 \%$ & $20,00 \%$ & $30,00 \%$ \\
\hline Change & $0,00 \%$ & $0,00 \%$ & $1,89 \%$ & $-11,11 \%$ & $2,86 \%$ \\
\hline
\end{tabular}

Table 13. The simulation results of GDP, INF, EXCH, INT increased 5\% simultaneously

\begin{tabular}{|l|l|l|c|c|c|}
\hline Calculation & IND & MLY & PLP & SNG & THL \\
\hline Base & $59,17 \%$ & $34,17 \%$ & $44,17 \%$ & $22,50 \%$ & $29,17 \%$ \\
\hline Simulation Result & $72,50 \%$ & $58,33 \%$ & $56,67 \%$ & $20,00 \%$ & $30,00 \%$ \\
\hline Change & $22,54 \%$ & $70,73 \%$ & $28,30 \%$ & $-11,11 \%$ & $2,86 \%$ \\
\hline
\end{tabular}

Table 14. The simulation results of GDP, INF, EXCH, INT decreased 5\% simultaneously

\begin{tabular}{|l|c|c|c|c|c|}
\hline Calculation & IND & MLY & PLP & \multicolumn{1}{c|}{ SNG } & THL \\
\hline Base & $59,17 \%$ & $34,17 \%$ & $44,17 \%$ & $22,50 \%$ & $29,17 \%$ \\
\hline Simulation Result & $40,00 \%$ & $18,33 \%$ & $14,17 \%$ & $24,17 \%$ & $25,83 \%$ \\
\hline Change & $-32,39 \%$ & $-46,34 \%$ & $-67,92 \%$ & $7,41 \%$ & $-11,43 \%$ \\
\hline
\end{tabular}

The simulation results based on table 5 on GDP increase by $5 \%$, the stock price index in Indonesia, Malaysia and the Philippines are sensitive and will be bullish. However, the stock price index Singapore and Thailand are not sensitive to increase in GDP of 5\%. The simulation results based on table 6 on GDP fall by 5\%, the stock price index in Indonesia and the Philippines will be bearish and the stock price index in Thailand will be bullish. On the other hand, the stock price index in Singapore and Malaysia is not sensitive to a decline in GDP of 5\%.

Table 7 explains that the stock price index in Singapore and Philippines is sensitive to an increase in inflation of 5\%, while in table 8 the stock price index in Malaysia and Thailand is sensitive to a decrease in inflation of 5\%. Table 7 and table 8 explain the Indonesian stock price index not sensitive to increasing or decreasing inflation of $5 \%$. 
Table 9 and table 10 explain the sensitivity simulation results of the stock price index of each of the five ASEAN countries with an increase or decrease in the exchange rate of $5 \%$. The simulation results conclude that the stock price index of five ASEAN countries is sensitive to the increase and decrease of the exchange rate.

The simulation results in table 11 describe the stock prices index of Malaysia, Singapore and the Philippines sensitive to an interest rate increase of $5 \%$, while the stock price index of Thailand, Singapore and the Philippines are sensitive to a decrease in interest rates of $5 \%$ in table 12 . Table 11 and table 12 explain Indonesian stock price index not sensitive to increasing or decreasing interest rates of $5 \%$.

The simulation results in table 13 show that all stock price indices are sensitive to the increase of 5\% macroeconomic variables in each ASEAN country, where the Indonesian, Malaysian, Philippine and Thai stock index are bullish, while the Singapore stock price index is bearish.

Singapore's economy is different compared to Indonesia, Malaysia, the Philippines and Thailand because Singapore is heavily dependent on income from exports of goods and services. If SGD strengthens against the USD, the price of export goods and services becomes expensive so that listed companies decline profits resulting in a bearish in the stock price index in Singapore.

The simulation results in table 14 show that all stock price index are sensitive to the decrease of 5\% macroeconomic variables in each ASEAN country, where the Indonesian, Malaysian, Philippine and Thai stock price index are bearish, while the Singapore stock price index is bullish.

\section{ARIMA method}

Autoregressive Integrated Moving-Average (ARIMA) calculations based on discriminant equation data and simulation results can be used as predictions the stock price index for the next six months in five ASEAN countries that have been summarized in table 8. The number 1 becomes an indicator for bullish and 0 becomes a bearish indicator to obtain prediction for next 6 months as follows:

Table 15. Predicted Stock Price Index 2016

\begin{tabular}{|c|c|c|c|c|c|}
\hline \multirow{2}{*}{ Month } & \multicolumn{5}{|c|}{ Classification } \\
\cline { 2 - 6 } & IND & MLY & PHL & SGP & THL \\
\hline M01-2016 & 1 & 1 & 1 & 0 & 1 \\
\hline M02-2016 & 1 & 1 & 1 & 0 & 1 \\
\hline M03-2016 & 1 & 0 & 1 & 0 & 1 \\
\hline M04-2016 & 1 & 0 & 1 & 0 & 1 \\
\hline M05-2016 & 1 & 0 & 1 & 0 & 1 \\
\hline M06-2016 & 1 & 0 & 1 & 0 & 1 \\
\hline
\end{tabular}


Table 16. Stock price index June 2015-2016

\begin{tabular}{|c|c|c|c|c|r|}
\hline \multirow{2}{*}{ Month } & \multicolumn{1}{|c|}{$\begin{array}{c}\text { IND } \\
\text { JCI }\end{array}$} & $\begin{array}{c}\text { MLY } \\
\text { KLSE }\end{array}$ & \multicolumn{1}{c|}{$\begin{array}{c}\text { PHL } \\
\text { PSE }\end{array}$} & $\begin{array}{c}\text { SGP } \\
\text { STI Index }\end{array}$ & $\begin{array}{c}\text { THL } \\
\text { SET Index }\end{array}$ \\
\hline June, 2015 & 4,971 & 1,734 & 7,535 & 3,342 & 2,219 \\
\hline June, 2016 & 4,982 & 1,646 & 7,830 & 2,846 & 2,231 \\
\hline Change (\%) & $0.22 \%$ & $-5.07 \%$ & $3.91 \%$ & $-14.84 \%$ & $0.54 \%$ \\
\hline
\end{tabular}

Source: finance.yahoo.com

The prediction result using ARIMA calculation based table 15 shows Malaysian and Singapore stock price index in the next 6 months of 2016 was bearish. Malaysia's KLSE June 2015 stock price index of 1,734 fell to 1,646 in June 2016 or decreased by $-5.07 \%$, as did the index of the Singapura stock price (STI Index) in June 2015 of 3,342 to 2,846 in June 2016, or decreased by $-14.84 \%$.

The Jakarta Composite Index (JCI) rose $0.22 \%$ from June 2015 by 4,971 to 4,982 in June 2016, as did the Philippine Stock Price Index (PSE) up by 3.91\% from June 2015 by 7,535 to 7,830 in June 2016. There was a bullish rise of the Thai stock price index (SET Index) of $0.54 \%$ from June 2015 of 2,219 to 2,231 in June 2016.

Based predict calculation using ARIMA that the stock price index Malaysia and Singapore were bearish. On the other hand, the stock price index Indonesia, the Philippines and Thailand were bullish. An early warning system to predict the stock price index of five ASEAN countries has provided results according to the ARIMA method as robustness test.

\section{CONCLUTION}

Simulation results increased and decreased GDP, inflation, exchange rate, and interest rate by 5 percent simultaneously making the stock price index in five ASEAN countries will react to be bullish or bearish. This means that the stock price index in ASEAN 5 countries were sensitive to changes in macroeconomic variables.

Increasing GDP, inflation, exchange rate, and interest rate by 5 percent simultaneously make stock price index in Indonesia, Malaysia, Philippines, Thailand tend to be bullish where Malaysia's stock price index has increased the highest bullish percentage, while the Singapore index is bearish.

The decline in GDP, inflation, exchange rates, and interest rates by 5 percent simultaneously made the stock price index in Indonesia, Malaysia, Philippines, Thailand tend to bearish where the Philippine share price index decreased the highest percentage of the stock, while the Singapore index was bullish.

The study concludes that simulation result of early warning system of each ASEAN 5 countries if the increase or decrease of macro economic variable hence impact on sensitivity of stock price index and behavior of ASEAN 5 countries either whole or individual country.

\section{References}

Al-Sharkas, A., The Dynamic Relationship Between Macroeconomic Factors and the Jordanian stock market. International Journal of Applied Econometrics and Quantitative Studies, 2004. Vol.1-1, p. 97-114.

Boonyanam, N., Relationship of stock price and monetary variables of Asian small open emerging economy: Evidence from Thailand. International Journal of Financial Research, 2014. 5(1), 52-63.

Box, G. E. P., et al., Time Series Analysis, Forecasting and Control, 3rd ed. Prentice Hall, 1994. Englewood Clifs, New Jersey. 
Brandt, M.W., and Kang, Q., On the relationship between the conditional mean and volatility of stock returns: a latent VAR approach. Journal of Financial Economics 2004. p. 217-257.

Hair, Jr., et al., Multivariate Data Analysis, 6th ed. 2006. Pearson International Edition.

Hamilton, J.D., and Lin, G., Stock market volatility and the business cycle. Journal of Applied Econometrics 1996.

Vol 11, 573-593.

Hardouvelis, Gikas A., Macroeconomic information and stock prices. Journal of Economics and Business 1987. Vol. 39, Issue 2, Pages 131-140.

Mankiw, N. Gregory., The Macroeconomist as Scientist and Engineer. Journal of Economic Perspectives, 2006. 20(4): 29-46.

Oseni, Isiaq O., and Nwosa, PI., Stock Market Volatility and Macroeconomic Variables Volatility In Nigeria: An Exponential GARCH Approach. Journal Of Economics And Sustainable Development 2011. Vol.2, No.10.

Oet, Mikhail V., et al., SAFE: An early warning system for systemic banking risk. Journal of Banking \& Finance, 2013. Elsevier

Pearce, Douglas K., and Roley, Vance., Stock Prices and Economic News. The Journal of Business, 1985. Vol. 58, No. 1, pp. 49-67

Schwert, G.W., Business cycles, financial crises and stock volatility. In: Carnegie-Rochester Conference Series on Public Policy, 1989. Vol. 31, pp. 83-125.

Shafana., Macroeconomic Variables Effect on Financial Sector Performance in Emerging Sri Lankan Stock Market. International Journal of Science and Research (IJSR), 2014. Vol. 3 Issue 10.

Shrimal, Kapil., and Prasad, Hanuman., Prediction of Market Capitalization Trend through

Selection of Best ARIMA Model with Reference to Indian Infrastructural Companies. International Journal of Applied Sciences and Management, 2016. Vol. 1, No. 2, 91-104.

Tabachnick, B.G., and Fidell, L.S., Using multivariate analysis. California State University Northridge: Harper Collins College Publishers, 2001.

Wahyudi, Sugeng., et al., Macroeconomic Fundamental and Stock Price Index in Southeast Asia Countries: A Comparative Study. International Journal of Economics and Financial, 2017.Issues 7(2), p. 182-187.

Yoon,W.J., and Park, K. S., A study on the market instability index and risk warning levels in early warning system for economic crisis. Digital Signal Processing: A Review Journal, 2014. Vol. 29. 